Indonesian Aquaculture Journal, 15 (2), 2020, 51-58

Available online at: http://ejournal-balitbang.kkp.go.id/index.php/iaj

\title{
OPTIMUM DENSITY OF Nannochloropsis sp. FOR MASS LARVAL REARING OF CORAL TROUT, Plectropomus leopardus (Lacepède, 1802)
}

\author{
Yasmina Nirmala Asih\#, Sudewi, Afifah Nasukha, Daniar Kusumawati, Ketut Mahardika, \\ Ahmad Muzaki, and I Nyoman Adiasmara Giri
}

Institute for Mariculture Research and Fisheries Extension
J. Br. Gondol Ds. Penyabangan Kec. Gerokgak Kab. Buleleng, Kotak Pos 140, Singaraja 81101, Bali, Indonesia

(Received:November 29, 2019; Final revised: August 3, 2020; Accepted: August 10, 2020)

\begin{abstract}
Coral trout, Plectropomus leopardus (Lacepède, 1802)is a visual feeder. Turbidity caused by phytoplankton or clay particle in the water will affect the visual foraging of coral trout larvae. Addition of Nannochloropsis $\mathrm{sp}$. has been included in standard operational procedure for marine fish larval rearing as green water. However, the density of Nannochlorposis sp. in coral trout larval rearing system has not been evaluated. This study aimed to evaluate the optimal of Nannochloropsis sp. required for rearing of coral trout larvae. Nannochloropsis sp. was given to two days old larvae (D-2), with the densities of $2 \times 10^{5}, 4 \times 10^{5}$, and $6 \times$ $10^{5} \mathrm{cell} / \mathrm{mL}$. After 50 days rearing period $(\mathrm{D}-50)$, evaluation on the average size and total harvest were recorded. The results showed that the density of $2 \times 10^{5}$ cell/mL Nannochloropsis sp. was the best in survival rate $(2.35 \pm 1.05 \%$ than other densities, but they were not significantly different $(P>0.05)$ than those of 4 $\times 10^{5} \mathrm{cell} / \mathrm{mL}\left(1.67 \pm 0.70 \%\right.$ and $6 \times 10^{5} \mathrm{cell} / \mathrm{mL}\left(1.26 \pm 1.05 \%\right.$. The lower densities, $2 \times 10^{5}$ and $4 \times 10^{5} \mathrm{cell} /$ $\mathrm{mL}$, were dominated by more than $50 \%$ of $>2.7 \mathrm{~cm}$ sized juvenile. Histological analysis of fish eyes supported that the two lower densities produced dominant cone shape as the receptor cells in the retina observed. From an economical aspect, addition of $2 \times 10^{5}$ cells $/ \mathrm{mL}$ resulted on the higher profit, hence optimum density of Nannochloropsis sp. added in coral trout larval rearing on a mass scale was $2 \times 10^{5}$ cells/mL.
\end{abstract}

\section{KEYWORDS: coral trout; larval rearing; Nannochloropsis sp.; turbidity}

\section{INTRODUCTION}

Appropriate feeding and water managements have pivotal roles in the larval rearing of coral trout, Plectropomus leopardus. The first critical stage was at the first feeding when the egg yolk had been absorbed completely, thus larvae should obtain the energy source out of their bodies to survive. The first feeding time for coral trout larvae is on day-3 when their egg yolks have been absorbed (Qu et al., 2012) and the mouth gap has opened completely (Sudewi et al., 2020). It was reported by Kusumawati et al. (2019) that feeding of live feed containing high fatty acid resulted in better survival for coral trout larvae. High fatty acid source could be obtained from Nannochloropsis sp. (Rebollosso-Fuenters et al.,

\footnotetext{
\# Correspondence: Institute for Mariculture Research and Fisheries Extension. Jl. Br. Gondol Ds. Penyabangan Kec. Gerokgak Kab. Buleleng, Kotak Pos 140, Singaraja 81101, Bali, Indonesia.

Tel. + 6236292272

E-mail: yasmien_na@yahoo.com
}

2011), which is also utilized as green water in the larval rearing.

Coral trout is a visual feeder fish (Yoseda et al., 2008), which deeply relies on their vision to capture the prey. The right amount of light intensity is required for the fish to enable distinguishing the prey and its surrounding. Research results of Andamari et al. (2007) regarding light intensities (0-1,200 lux) for coral trout larval rearing showed range of light intensity from 900 to 1,200 resulted the highest survival by the end of larval rearing. This result was accordance with Yoseda et al. (2008) who reported that coral trout at 5 days after hatching (DAH) had better survival when rearing in levels of light intensity 1,000-3,000 lux than of 0-500 lux.

Light entering into water will be absorbed or scattered by particles (Sandstrom, 1999; Utne-Palm, 2002; Wellington et al., 2010), known as turbidity. Level of turbidity affects the vision of fish and its behavior in foraging (Cutts \& Batty, 2005; Utne-Palm, 2002). According to Cutts $\&$ Batty (2005), level of 
turbidity was highly correlated to the density of phytoplankton in the water. Effect of turbidity depends on the development stage of the fish, since the dominancy of rod or cone cells which are photoreceptor cells in the eyes determine the function of vision. Cone cells work better in higher light intensity than rod cells and vice versa (Sandstrom, 1999).

Optimum levels of turbidity increase the vision of fish larvae to detect the prey and provide a safety sense from predator during foraging (Utne-Palm, 2002). Wellington et al. (2010) argued that low level of turbidity will benefit larvae by increasing contrast between live feed (zooplankton) and its surrounding. This arguably will improve the ability of fish to detect and capture the zooplankton. Survival of fish increases with the increasing of feeding success. However, in the larval rearing of humpback grouper, density of phytoplankton $5 \times 10^{5}$ cells $/ \mathrm{mL}$ resulted in the higher survival compared to those reared in lower density of phytoplankton $3 \times 10^{5}$ and $1 \times 10^{5}$ cells $/ \mathrm{mL}$ (Ismi et al., 2012). The function of phytoplankton as green water in the larval rearing water may explain of those results. Adding shading with green water might increase the foraging activity of the fish in looking for preys (Li et al., 2013). Different species might require different optimum density of phytoplankton in their environment. Hence, the objective of the research is to evaluate the optimum amount of addition of phytoplankton in coral trout, Plectropomus leopardus larval rearing water.

\section{MATERIALS AND METHODS}

\section{Larval Rearing}

This study was conducted in a closed hatchery using concrete yellow tanks with volume of $5000 \mathrm{~L}$. Tanks were covered with transparent plastic to stabilize water temperature during the night. Approximately 50,000 eggs were stocked into each larval tank. Standard protocol in rearing coral larval trout was given on Table 1.

In the current study, a modification was created by treating the system with different densities of Nannochloropsis sp. given.

\section{Experiment}

Experiment was conducted at Gondol Research Insitute for Mariculture from March to December 2017. Plankton used was obtained from mass-cultured as much as $60 \mathrm{~L}$, which was counted every day for the density and added with frozen concentrate (Nanno3600®) for the remaining amount. Larval rearing water was treated with different of Nannochloropsis sp. densities $2 \times 10^{5}, 4 \times 10^{5}$, and $6 \times$
$10^{5}$ cells $/ \mathrm{mL}$. Each density treatment was repeated three times using the tanks of 5,000 L. Nannochloropsis sp. was given from two days old larvae (D-2) to D-30, once a day using two aeration hoses. Total of nine tanks were used for the larval rearing with number of initial larvae was approximately 31,000 larvae which was counted from hatching rate of eggs $(62 \%$.

The number of rotifers in the larval gut was counted by squishing the larval stomach from D-3 to D-8 when the stomach started to harden. Growth of larvae was also observed on interval days, every two days from $D-1-D-10$, and every five days from D-10- D-40. Both observations were performed under microscope and as many as 10 fish were observed for each sample. Survival rate, size diversity and percentage of deformities were calculated at harvest, which was executed manually by sorting the fish based on their size and performance (deformed or normal).

Histology observation, particularly on the eyes development of the fish was focused on the dominancy of rod or cone cells. Levels of turbidity, $\mathrm{pH}$, ammonium $\left(\mathrm{NH}_{4}\right)$, and nitrite $\left(\mathrm{NO}_{2}\right)$ were checked at 2-day interval up to D-20, and at 5-day interval afterwards up to D-40.

\section{RESULTS AND DISCUSSION}

\section{Survival and Size Variation}

Addition of Nannochloropsis sp. in coral trout larval rearing with a density of $2 \times 10^{5}$ cells $/ \mathrm{mL}$ resulted higher survival $(2.35 \pm 1.05 \%$ but not significantly different $(P>0.05)$ compared to those reared in densities of $4 \times 10^{5}$ cells $/ \mathrm{mL}\left(1.67 \pm 0.70 \%\right.$ and $6 \times 10^{5}$ cells $/ \mathrm{mL}(1.26 \pm 1.05 \%$. However, the survival was still highly fluctuated based on the value of standard deviation. This contrasted study of humpack grouper larval rearing, in which the survival tent to increase with the increasing of Nannochloropsis sp. density (Ismi et al., 2012).

At the end of the experiment (D-50), observation was conducted by harvesting all of the fish to count survival, percentage of deformities, and variation of the grade (size). Deformities such as lordosis, scoliosis, twisted jaws, or shorten operculum were hardly detected at this stage. The percentage of size variation was presented in Table 2 .

Addition of 600,000 cells $/ \mathrm{mL}$ of Nannocloropsis sp. resulted higher percentage of variation than those of two other treatments. Addition of $2 \times 10^{5} \mathrm{cells} / \mathrm{mL}$ resulted in homogenous size $(>2.7 \mathrm{~cm}$ ) of the juvenile around $52.3 \%$ while addition of $4 \times 10^{5}$ cells $/ \mathrm{mL}$ resulted more homogenous size $(>2.7 \mathrm{~cm})$ around $63.5 \%$ This might be due to the light and turbidity 
Table 1. Feeding and water exchange management in coral trout, Plectropomus leopardus larval rearing

\begin{tabular}{|c|c|}
\hline & Days \\
\hline & 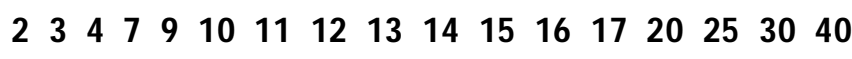 \\
\hline \multicolumn{2}{|l|}{ Feeding management } \\
\hline \multicolumn{2}{|l|}{ Nannochloropsis sp. } \\
\hline \multicolumn{2}{|l|}{ Rotifers } \\
\hline \multicolumn{2}{|l|}{ Nauplii copepods } \\
\hline \multicolumn{2}{|l|}{ Formulated feed } \\
\hline \multicolumn{2}{|l|}{ Nauplii Artemia } \\
\hline \multicolumn{2}{|l|}{ Mysids } \\
\hline \multicolumn{2}{|l|}{ Water exchange management } \\
\hline \multicolumn{2}{|l|}{$5 \% 10 \%$} \\
\hline \multicolumn{2}{|l|}{$10 \% 25 \%$} \\
\hline$\geq 25 \%$ increased gradually up to $100 \%$ & \\
\hline Siphoning & \\
\hline
\end{tabular}

Tabel 2. Size variation of coral trout seed resulted from larval rearing with densities of Nannochloropsis sp. $2 \times 10^{5} ; 4 \times 10^{5}$; and $6 \times 10^{5}$ cells $/ \mathrm{mL}$

\begin{tabular}{cccc}
\hline $\begin{array}{c}\text { Addition of } \\
\begin{array}{c}\text { Nannochloropsis sp. } \\
\text { (cells/mL) }\end{array}\end{array}$ & $\begin{array}{c}\text { Large } \\
(\mathbf{2 . 7} \mathbf{~ c m}) \\
(\%)\end{array}$ & $\begin{array}{c}\text { Medium } \\
(\mathbf{2 . 5 - 2 . 7} \mathbf{~ c m}) \\
(\%)\end{array}$ & $\begin{array}{c}\text { Small } \\
<\mathbf{2 . 5} \mathbf{~ c m}) \\
(\%)\end{array}$ \\
\hline $2 \times 10^{5}$ & 52.3 & 20.2 & 27.5 \\
$4 \times 10^{5}$ & 63.5 & 13.05 & 23.45 \\
$6 \times 10^{5}$ & 31.4 & 37.5 & 31.1 \\
\hline
\end{tabular}

conditions in the larval rearing water of those two treatments provide better condition to forage. Hence fish were more active and easier to capture preys, which encourage the similar growth of fish in the same population.

\section{Numbers of Rotifer in The Fish Gut and Fish Growth}

Observation in the fish gut to understand the amount of rotifers captured and eaten by the larvae showed that addition of Nannochloropsis sp. $4 \times 10^{5}$ cells/mL as greenwater in the water resulted in frequently higher incidence of rotifer consumption than addition of Nannochloropsis sp. $2 \times 10^{5}$ and $6 \times 10^{5}$ cells/mL (Figure 1 ) during the early feeding. However, all of the treatments showed positive results in which fish was able to capture rotifer. The success of fish to capture rotifers during the first feeding was pivotal to ensure the survival of the fish since yolk sac of coral trout as endogenous source of energy was absorbed 3 days after hatching (Qu et al., 2012), which means that the larvae should be able to obtain exogenous energy from rotifers to maintain metabolism function.

However, even though the addition of $4 \times 10^{5}$ cells/ $\mathrm{mL}$ had higher rate of rotifer consumption, the growth of all the treatments were similar (Figure 2) during the rearing. At the end of the experiment, addition of $4 \times 10^{5}$ cell $/ \mathrm{mL}$ resulted in a slight bigger growth than the others. This was in accordance with the variation size data above. Total length of coral trout juvenile on D-40 was approximately $14-15 \mathrm{~mm}$ and on D-50 could reach $2.7 \mathrm{~cm}$.

Turbidity levels showed consistently increased with the increasing of Nannochloropsis sp. additions in the larval rearing water. Addition of Nannochloropsis $\mathrm{sp}$. at $6 \times 10^{5}$ cells $/ \mathrm{mL}$ resulted in the highest turbidity level followed by $4 \times 10^{5}$ and $2 \times 10^{5}$ cells $/ \mathrm{mL}$, respectively (Figure 3 ). Turbidity level was highly related to light intensity penetrated to rearing water and affected to vision of larvae to detect the prey. Turbidity levels determine the contrast between preys and the surrounding, thus it immensely affects the 


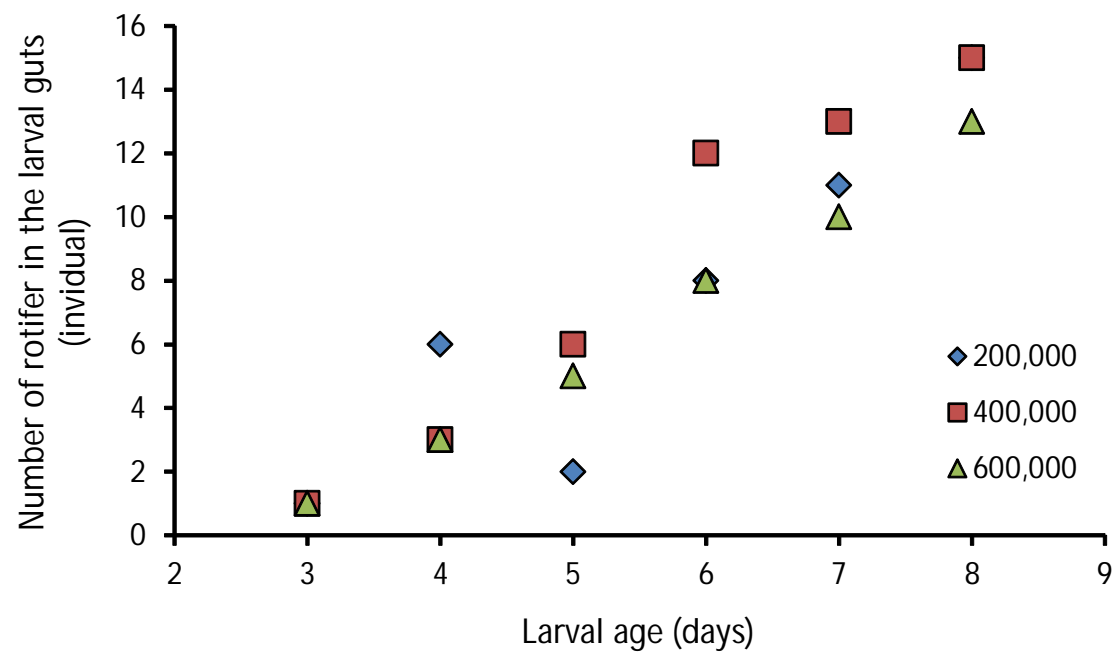

Figure 1. Numbers of rotifers (individual) observed in the fish gut on day3 to day-8.

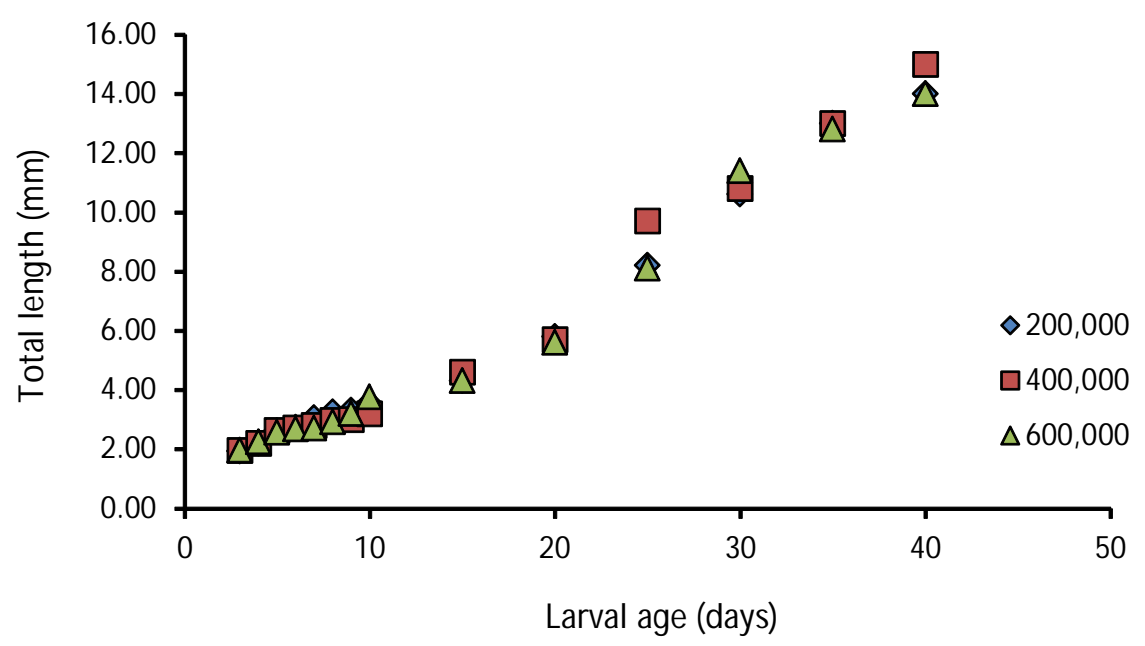

Figure 2. Total length of fish during larval rearing up to day-40.

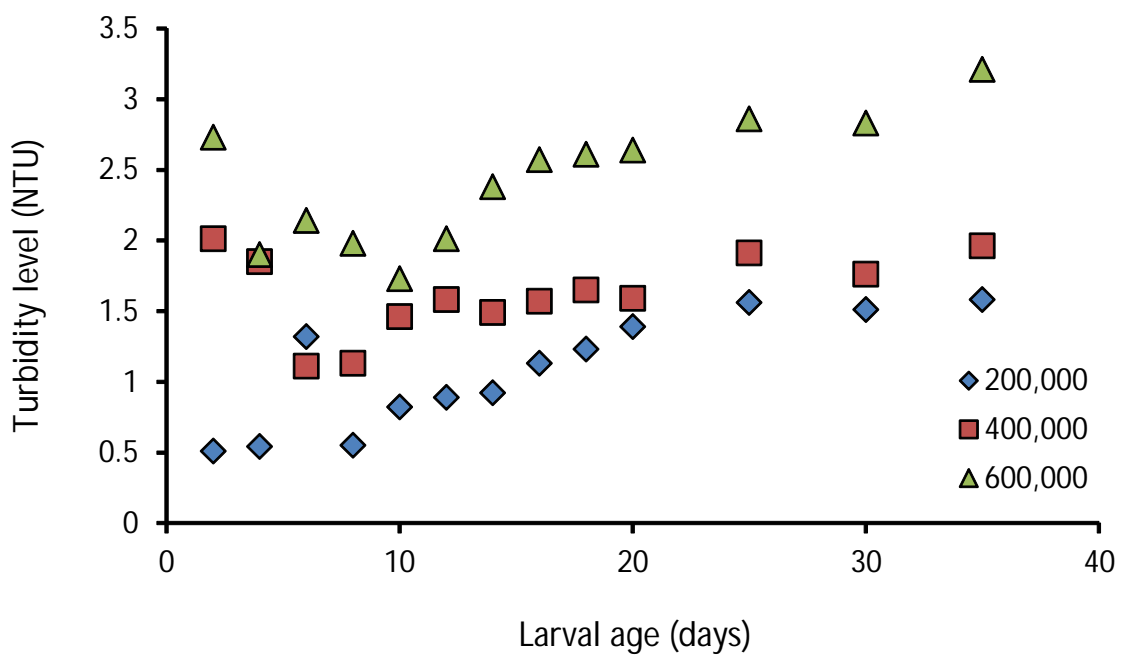

Figure 3. Turbidity level (NTU) of larval rearing water. 
ability of fish to detect the preys accurately. Study conducted by Cutts \& Batty (2005) found that turbidity level due to low density of phytoplankton (1.79 NTU) resulted in more contrast between Artemia and the background. Hence the success rate of fish detects and capture Artemia increased due to the contrast. This may also explain fish with addition of $4 \mathrm{x}$ $10^{5}$ cells $/ \mathrm{mL}$ had higher growth and higher percentage of large size of juvenile at the end of the experiment since the larvae capture Artemia better during the rearing.

\section{Eye Histology}

Eye histology was observed to find out the development of the coral trout larvae and its vision ability in the light or dark condition. The results showed that eye of the fish had been completely developed on D-3, showed by complete structure and pigmentation (Figure 4). This indicates that coral trout larvae started to be actively foraging and preying since $\mathrm{D}-3$.

Results of histology also revealed that eye of coral trout larvae was dominated by cone cells as the receptor cells than by rod cells (Figure 5). Ratio of cone and rod cells (Table 3 ) ranged from 1.3 to 3.8, which means that the number of cone cells were higher than the number of rod cells during larval stage of coral trout. This signified that coral trout larvae required relatively high light intensity in order to see and differentiate colors. Cone cells are the photoreceptor cells which work better in light condition, while rod cells work better in low light intensity or dark (Kjorsvik et al., 2004; Monk J. et al., 2006; Villamizar et al., 2011). According to Monk J. et al. (2006), pelagic larvae of marine fish tend to have higher number of cone cells than rod cells. The number of rod cells increases as the development of the fish, thus fish will be adapted to the darker environment as they grow.

\section{Water Quality}

During the rearing, generally ammonium $\left(\mathrm{NH}_{4}\right)$ levels in the rearing water increased considerably after D- 6 and reached highest level on D-10 around 1 ppm (Figure 6). This was expected since water exchange and siphoning had not been initiated until D-10. However, level of ammonium 1 ppm was considered unfavorable for some grouper larvae. Sugama et al. (2012)

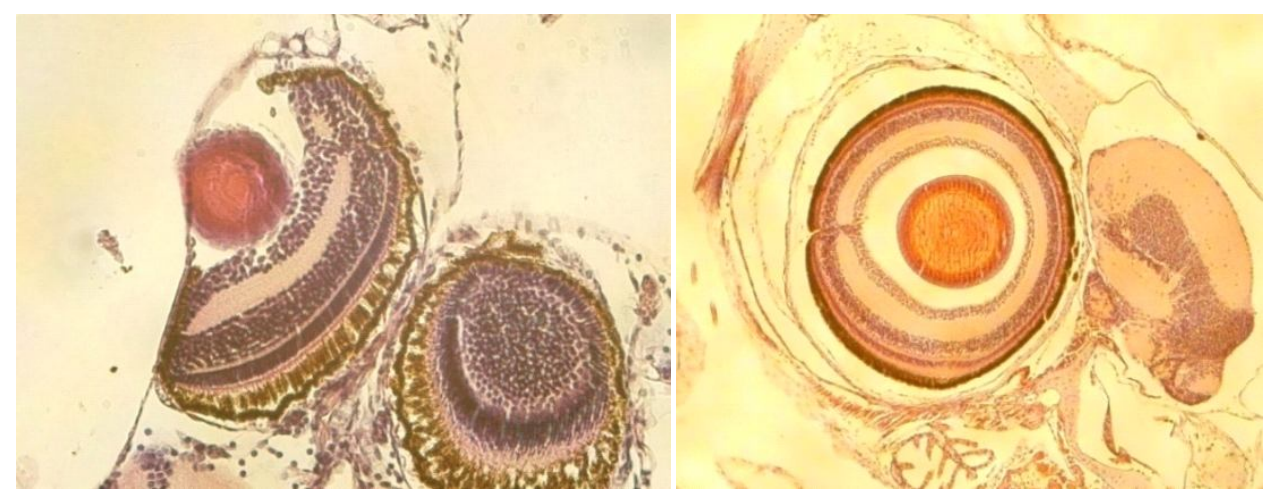

Figure 4. Eye histology of coral trout, Plectropomus leopardus larvae day-3 (left) and day-20 (right) (400x).

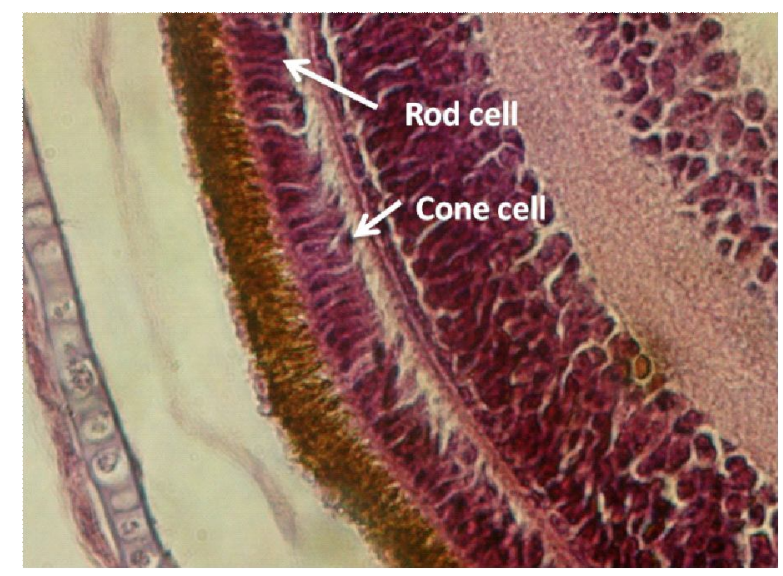

Figure 5. Cone and rod cells of coral trout, Plectropomus leopardus eye $(1,000 x)$. 
Table 3. Ratio of cone and rod cells in the eye of coral trout larvae per $100 \mu \mathrm{m}$

\begin{tabular}{cccc}
\hline \multirow{2}{*}{$\begin{array}{c}\text { Larval age } \\
\text { (days) }\end{array}$} & \multicolumn{3}{c}{ Addition of Nannochloropsis sp. (cells $/ \mathbf{m L}$ ) } \\
\cline { 2 - 4 } & $\mathbf{2 \times 1 \mathbf { 1 0 } ^ { \mathbf { 5 } }}$ & $\mathbf{4 \times 1 0 ^ { \mathbf { 5 } }}$ & $\mathbf{6 \times 1 0 ^ { \mathbf { 5 } }}$ \\
\hline 3 & 2.6 & 1.6 & 1.6 \\
5 & 2.3 & 3.5 & 1.7 \\
10 & 2.3 & 2.1 & 1.8 \\
15 & 2.0 & 3.8 & 1.6 \\
20 & 1.5 & 1.3 & 2.6 \\
\hline
\end{tabular}

recommended maintaining level of ammonia in tiger grouper larval rearing below $0.1 \mathrm{ppm}$. Feces, dead rotifer and phytoplankton were accumulated in the water since the beginning of the larval rearing. It led to the loading of organic matter which converted to ammonia. After water exchange on D-10 and siphoning on D-12, the ammonium levels were noticeably dropped to $0 \mathrm{ppm}$. This pattern of ammonia levels was in accordance with the research report of Kusumawati et al. (2019) on coral trout larval rearing with similar protocol which ammonia level peaked on day 10-15 with levels of 1.5-2.5 ppm and decreased significantly after siphoning.

In general, higher density of phytoplankton added in the rearing water resulted in the increasing levels of ammonium. Dead phyto plankton added the amount of organic matter in the water. In this experiment, not only cultured Nannochloropsis sp. added in the larval rearing but also paste/concentrated Nannochloropsis sp. which tends to drop in the bottom after 4-5 days.

In contrast with the ammonia levels pattern in the rearing water, increasing of nitrite $\left(\mathrm{NO}_{2}\right)$ was only detected after D-14 and rise gradually up to D-40 (Figure 7). Higher levels of nitrite were resulted from higher density of Nannochloropsis sp. added in the water. Nitrite is notoriously toxic to fish, however each species has different toxic levels. A study conducted on gila trout Oncorhynchus gilae showed that $10 \mathrm{ppm}$ of nitrite was able to kill the fish after 96 hours (Fuller et al., 2003). While Parra \& Yufera (1999) reported that larvae of gilt head seabream could tolerate nitrite level of 200 ppm after 24 hours. High levels of nitrite exposure with relatively long duration might influence the survival of coral trout and there should be a further investigation.

While levels of oxygen during rearing ranged from 4.5 to $6.4 \mathrm{ppm}$. Research result on larval rearing reported by Kusumawati (2019) showed that DO levels during coral trout larval rearing were above 5 to 7 ppm. Based on the ammonia and nitrite data which were considerably higher than recommended (Sugama et al., 2012), this concern should be addressed in the future research which might lead to increasing of survival rate.

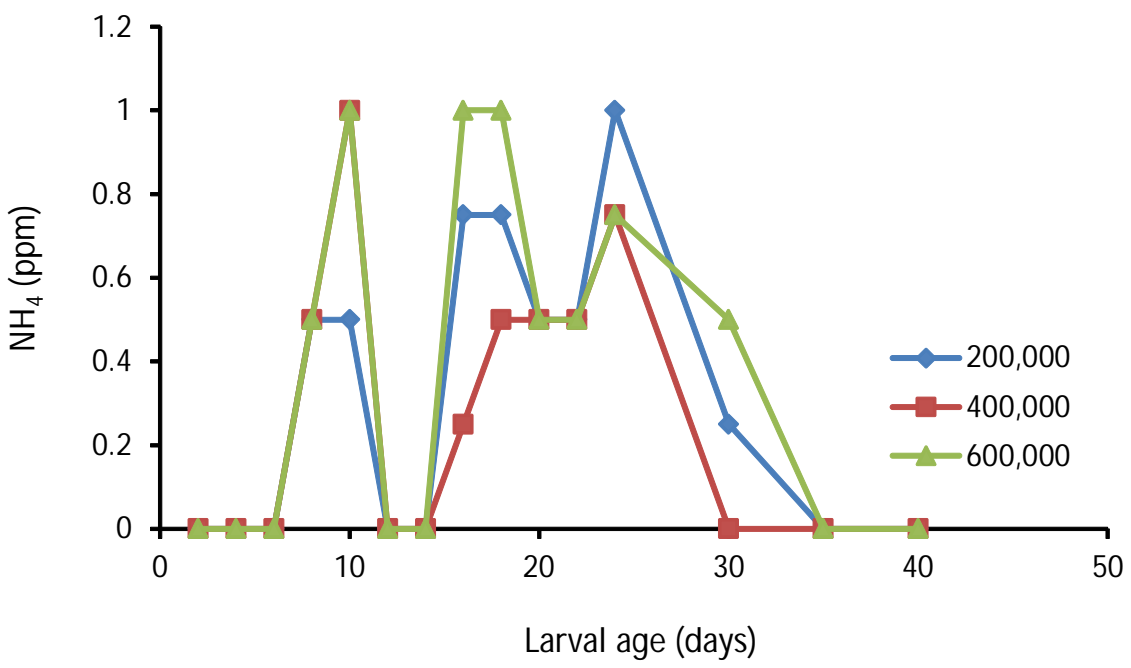

Figure 6. Ammonium $\left(\mathrm{NH}_{4}\right)$ levels $(\mathrm{ppm})$ during coral trout larval rearing. 


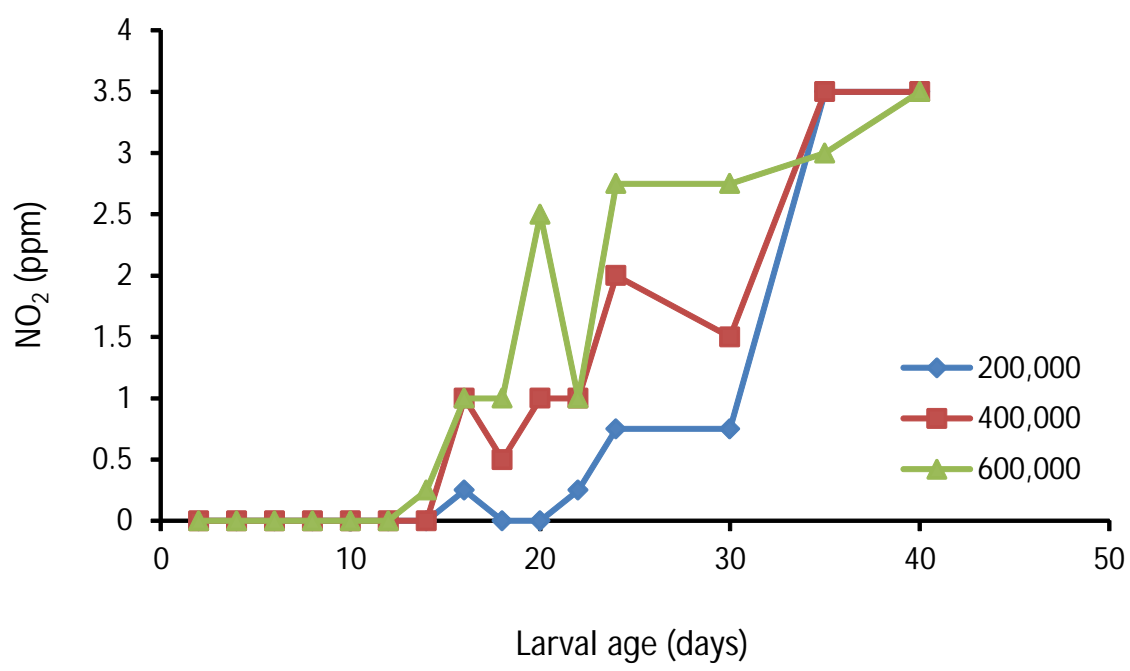

Figure 7. Nitrite $\left(\mathrm{NO}_{2}\right)$ levels $(\mathrm{ppm})$ during coral trout larval rearing.

\section{Profit Analyses}

Since the survival among treatments were not significantly different. An economical factor was considered to determine the optimum density needed for larval rearing. Profit of mass scale larval rearing of coral trout was calculated based on the cost of Nannochloropsis sp. concentrate added in the water, feed cost and the revenue of the fingerlings harvested on D-50, since those were the differential factors in determining the profit in this study. Feed cost of larval rearing was IDR 1,135/fish. Revenue was calculated on the price of fish based on the size (refers to Table 2). The cost of Nannochloropsis sp. concentrate was IDR $1,100 / \mathrm{mL}$ and the price of the fingerlings was based on its size (large: IDR 5,400; medium: IDR 4,860; and small: IDR 4,500) (Tabel 4).

\section{CONCLUSION}

Addition of Nannochloropsis sp. at density of $2 \mathrm{x}$ $10^{5}$ cell $\mathrm{s} / \mathrm{mL}$ would be suitable in the larval rearing of coral trout, Plectropomus leopardus. Coral trout larva's retina was dominated by cone cells instead of rod cells, thus their vision was better in lighter condition than darker condition. Hence, addition of high density of Nannochloropsis sp. hindered the ability of the larvae to detect prey. However, right amount of green water density was necessary to stimulate foraging activity and improve vision of the larvae. Also addition of $2 \times 10^{5}$ cells $/ \mathrm{mL}$ would be more favorable from an economical aspect for production of coral trout due to its value of profit (IDR 3,777 per fish).

\section{REFERENCES}

Andamari, R., Ismi, S., Wardoyo., \& Marzuki, M. (2007). Coral trout (Plectropomus leopardus) larval rearing in different photoperiods and light intensities. Technical Report of Research Institute for Mariculture 2007. Research Institute for Mariculture, Gondol Bali. (in Indonesian).

Cutts, C.J. \& Batty, R.S. (2005). Progress report on 'algal-mediated turbidity and larval performance

Table 4. The cost and revenue of a mass scale coral trout, Plectropomus leopardus larval rearing added with different densities of Nannochloropsis sp. values presents as IDR

\begin{tabular}{|c|c|c|c|}
\hline & \multicolumn{3}{|c|}{$\begin{array}{l}\text { Density of Nannochloropsis sp. } \\
\text { added in the larval rearing water } \\
\text { (cells } / \mathrm{mL} \text { ) }\end{array}$} \\
\hline & $2 \times 10^{5}$ & $4 \times 10^{5}$ & $6 \times 10^{5}$ \\
\hline $\begin{array}{l}\text { Nannochloropsis sp. } \\
\text { concentrate cost }\end{array}$ & 95.7 & 287.1 & 861 \\
\hline Feed cost & 826.641 & 587.443 & 411.562 \\
\hline Revenue & $3,674,131$ & $2,649,837$ & $1,783,614$ \\
\hline Profit & $2,751,790$ & $1,775,294$ & 511.052 \\
\hline Profit per fish & 3.777 & 3.429 & 1.409 \\
\hline
\end{tabular}


in marine fish: Primary milestone-1, The effect of turbidity on fish vision. SAMSardtoe, Argyll., $11 \mathrm{pp}$.

Fuller, S.A., Henne, J.P., \& Carmichael, G.J. (2003). Toxicity of ammonia and nitrite to the gila trout. North American Journal of Aquaculture, 65, 162-164.

Ismi, S., Asih, Y.N., Slamet, B., \& Suwirya, K. (2012). Optimum density of Nannochloropsis sp. in larval rearing of humpback grouper (Cromileptes altivelis). Jurnal Riset Akuakultur, 7(3), 407-419.

Kjorsvik, E., Pittman, K., \& Pavlov, D. (2004). From fertilisation to the end of metamorphosis-functional development. In: Moksness, E., Kjorsvik, E., \& Olsen, Y. (Eds.), Culture of cold-water marine fish. Oxford: Blackwell Publishing Ltd., p. 230-231.

Kusumawati, D., Asih, Y.N., \& Setiawati, K.M. (2019). Increasing survival rate of coral trout (Plectropomus leopardus) larvae by using properly larval rearing management. Berita Biologi (Jurnal IImu-ilmu Hayati), 18(1), 59-70. DOI: 10.14203/ beritabiologi.v18i1.2951. (Indonesian with English abstract).

Li, W., Zhang, T., Zhang, C., Li, Z., Liu, J., \& Hicks, B.J. (2013). Effects of turbidity and light intensity on foraging success of juvenile mandarin fish Siniperca chuatsi (Basilewsky). Environ. Biol. Fish., 96, 995-1002. DOI: 10.1007/s10641-012-0096-0.

Monk, J., Puvanendran, V., \& Brown, J.A. (2006). Do different light regimes affect the foraging behaviour, growth and survival of larval cod (Gadus morhua L.)?. Aquaculture, 257(1-4), 287-293.

Parra, G. \& Yúfera, M. (1999). Tolerance response to ammonia and nitrite exposure in larvae of two marine fish species (gilthead seabream Sparus aurata L. and Senegal sole Solea senegalensis Kaup). Aquaculture Research, 30 (11 12), 857-863.

Qu, M., Ding, S., Xu, X., Shen, M., You, Y., \& Su, Y. (2012). Ontogenic development of the digestive system and growth in coral trout (Pletropomus leopardus). Aquaculture, 334-337, 132-141.
Rebolloso-Fuentes, M.M., Navarro-Perez, A., GarciaCamacho, F., Ramos-Miras, J.J., \& Guil-Guerrero, J.L. (2001). Biomass nutrient profiles of the microalga Nannochloropsis. J. Agric. Food. Chem., 49(6), 2996-2972.

Sandstrom, A. (1999). Visual ecology of fish: A review, with special reference to percids. Fiskeriverket Rapport, 2, 45-80.

Sudewi, Asih, Y.N., \& Nasukha, A. (2020). A study on mouth gap of coral trout (Plectropomus leopardus) and its suitability for live feed sizes. Journal of Fisheries and Marine Research, 4, 87-93.

Sugama, K., Rimmer, M.A, Ismi, S., Koesharyani, I., Suwirya, K., Giri, N.A., \& Alava, V.R. (2012). Hatchery management of tiger grouper (Epinephelus fuscoguttatus): A best-practice manual. Canberra: ACIAR Monograph No. 149, Australian Centre for International Agriculture Research, $66 \mathrm{pp}$.

Utne-Palm, A.C. (2002). Visual feeding of fish in a turbid environment: Physical and behavioural aspect. Marineand Freshwater Behaviour and Physiology, 35, 111-128.

Villamizar, N., Blanco-Vives, B., Migaud, H., Davie, A., Carboni, S., \& Sanchez-Vazquez, F.J. (2011). Effects of light during early larval development of some aquacultured teleosts: A review. Aquaculture, 315, 86-94.

Wellington, C.G., Mayer, C.M., Bossenbroek, J.M., \& Stroh, N.A. (2010). Effects of turbidity and prey density on the foraging success of age 0 year yellow perch Perca flavescens. Journal of Fish Biology, 76, 1729-1741.

Yoseda, K., Yamamoto, K., Asami, K., Chimura, M., Hashimoto, K., \& Kosaka, K. (2008). Influence of light intensity on feeding, growth and early survival of leopard coral grouper (Plectropomus leopardus) larvae under mass-scale rearing conditions. Aquaculture, 279, 55-62. 